\title{
Euthanasia and suicide in antiquity: viewpoint of the dramatists and philosophers
}

\author{
John D Papadimitriou Panayiotis Skiadas Constantinos S Mavrantonis \\ Vassilis Polimeropoulos Dimitris J Papadimitriou Kyriaki J Papacostas
}

J R Soc Med $2007 ; \mathbf{1 0 0 : 2 5 - 2 8}$

'It is not the death I fear to face but dying.'

Robert Louis Stephenson, British Medical Bulletin 1926; 52:246-254

Although more than 3000 years have passed, the dilemma posed by euthanasia still generally divides society - a vexed question which has been debated in the medical, legal, philosophical and theological literature.

In antiquity, active euthanasia and suicide were subjects of concern. Active euthanasia was rejected by the majority of both philosophers and dramatists because it was considered to be a violation of the autonomy of the individual and an action against the will of the gods.

Passive euthanasia was more acceptable, either on the grounds of physical pain or out of a deep respect for the nature of human life and what fate brings to it.

Even though innovations in palliative medicine can offer the best possible quality of life, there is still a minority of patients who suffer from excruciating pain, be it physical or mental. For these patients, it is the primary duty of the physician to alleviate the pain or other sufferings, provided that the doctor plays no role in initiating the course of death, at least in countries where active euthanasia is not legally permitted.

\section{INTRODUCTION}

Euthanasia has been a subject of controversy for more than three thousand years. ${ }^{1}$ The word 'euthanasia', which is Greek in origin (EY-@ANATO $\Sigma=\operatorname{good}$ death), appears during the Hellenistic period. Authors in antiquity indirectly talked about 'willing self-sacrifice' or 'intended death' or 'death brought about by an action of one's own.' Apart from Hippocrates, many philosophers-Pythagoras, Socrates, Aristotle, Plato, Epicurus and others-indirectly dealt with euthanasia.

In the Greek tragedies, which are counted among man's highest achievements, the reader is taught not only about music, dance and spectacles, but also about ethics.

Err. Dunant Hospital, Surgical Services, 107-9 Mesogion Avenue, Block A/7th Floor, Athens, Greece

Correspondence to: John D Papadimitriou MD FACS

E-mail: ipapadim@dunant.gr
The greatest of the dramatists/tragedians were Aeschylus, who was referred to as 'the perfect one,' the humane and popular Sophocles and the eminent Euripides, who all touched upon the ethical aspects of euthanasia in their plays.

Euthanasia continues to be a matter in dispute in modern medicine and questions about its clinical necessity are still being debated in the literature.

\section{THE DRAMATISTS}

The Greek tragedians in antiquity were the first to use nearly all of the literary forms which exist nowadays: tragedy, comedy, epic and romance. ${ }^{2}$ The three tragedian giants were Aeschylus, Sophocles and Euripides.

Aeschylus, who was regarded as the father of tragedy, was born in Elefsis in c. $525 \mathrm{BC}$ and died in $456 \mathrm{BC}$. He was the earliest of the dramatists whose work has survived; his famous predecessors included Thespis, Pratinos, Phrynichus and others whose works have been lost. The performances were of a religious origin, and were part of the cult of Dionysos. ${ }^{3}$

It has been estimated that Aeschylus wrote between 70 and 90 tragedies, but only seven have come down to us. Some are very well known, such as Seven against Thebes and the Oresteia (consisting of Agamemnon, Choephori and Eumenides), which is the only surviving trilogy and which represents not only Aeschylus' greatest achievement, ${ }^{4}$ but is most probably among 'the greatest work[s] of dramatic art ever created.' 5

In the Aeschylian classic drama Prometheus Bound $d^{4-6}$ one of the characters, Eos, who has become desperately entrenched in psychological problems, says that it is better for one to die than to suffer every day. It appears that Aeschylus was not against euthanasia. 'It were better to die once and for all than to drag out my lingering days in anguish.' 7 a

Sophocles $^{8-11}$ was born in c. 495 BC and died in 406 $\mathrm{BC}$; his family was of very comfortable means. A handsome and successful athlete and musician, he enjoyed the high esteem of his fellow citizens, holding both political and religious office. Sophocles' profound respect for the gods resulted in his strictly negative viewpoint with regard to 
euthanasia. He believed that life was the highest good given to mankind by the gods.

Seven Sophoclean tragedies have survived, spanning some 40 years or more. ${ }^{8}$ Sophocles was the recipient of numerous awards for his plays. In Antigone ${ }^{10}$ he states that nobody is so silly as to wish to die: 'Who prays to die is mad.' 'No man is so foolish that he is enamoured of death. ${ }^{7 b}$ However, in another play, The Women of Trachis, ${ }^{11}$ he refers to the dilemma presented by assisted euthanasia: The protagonist Heracles, who is suffering from unbearable pain, asks his son, Hyllus, to help him end his life: 'Lay my body thereupon and kindle it with flaming pine-torch. And let no tear of mourning be seen there. ${ }^{\text {'c }}$ Hyllus complains that in so doing, he will 'become a murderer' and will be showing disrespect to the gods. 'What a deed dost thou require of me my father that I should become the murderer guilty of thy blood. '7c 'Father, father, how can you? You are asking me to be your murderer, polluted with your blood.' And Heracles replies: 'No, I am not. I ask you to be my healer,' 11 or '(be) healer of my sufferings, sole physician of my pain. ${ }^{7 c}$

Euripides, who was born on the island of Salamis in c. $480 \mathrm{BC}$ and died in $406 \mathrm{BC}$, was the most modern of the three dramatists; he wrote more than 100 plays, of which 18 have survived and others are known in fragments. Among his innovations were the introduction of realism and a machine appearing from the heavens, out of which comes a god: when the play proceeds to its conclusion, this divine being seems to resolve the impasse, offering a solution.

Unlike Sophocles, Euripides won few awards. ${ }^{12-16} \mathrm{He}$ believed that man is responsible for his actions and on at least two occasions in his plays, individuals seek euthanasia. In Iphigeneia in Taurica, Orestes, who suffers psychologically, tries to put an end to his life by starving himself to death. He writes: ${ }^{12,13}$ 'Fasting before his shrine I cast me down and swore to snap my life threat, dying there I.' However, Euripides admires life and his attitude is one which is against euthanasia. In his play Iphigeneia in Aulis ${ }^{14}$ he writes: 'Ill life o'er passeth gracious death.' And lastly, in his play The Madness of Hercules, ${ }^{15,16}$ he puts the following words in the mouth of his hero: 'Yet, thus I have musedhow deep soe'er in ills - shall I quit life and haply prove me craven?' Or, 'I will be strong to await death.'16

\section{THE PHILOSOPHERS}

Philosophers always seem to be dealing with death.

We have learned from Plato, ${ }^{17,18}$ one of the giants of philosophy in antiquity, that Asclepius, the god of healing and medicine, believed that in cases where there was no feasible effective treatment and when life expectancy was short, the physician could refuse to administer any kind of treatment, since to treat such a patient would be of no benefit to the person or to society.

Pythagoras is considered to be one of the greatest philosophers and mathematicians in ancient Greece. Born on the island of Samos in c. 580 BC, he died in southern Italy in approximately $500 \mathrm{BC}$. Pythagoras founded the Pythagorean School, which was active from the 6th century $\mathrm{BC}$ until the first post-Christian centuries.

Pythagorean philosophers believed in the transmigration of the soul and, based on a combination of philosophical and theological beliefs about life, they were against a voluntary end to life because all life is sacred. ${ }^{19}$ For the same reason, even surgical procedures were forbidden.

Plato was born in c. $427 \mathrm{BC}$ and died in $347 \mathrm{BC}$, but only during the last decade of his life did he begin to write his dialogues. ${ }^{20-24} \mathrm{~A}$ pupil of the great teacher Socrates, Plato is considered to be one of the greatest philosophers ever born.

Believing in the harmony of life, Plato was against what nowadays is called active euthanasia. In his $\operatorname{Laws}^{20}$ he suggests in a general way that doctors should be punished by death, if by administering any sort of drug they contribute to the termination of life. Moreover, in Phaedo he opposes a man who committed suicide because it is against the will of the gods and thus not allowed. ${ }^{21}$

However, although Plato states that those who commit suicide should be buried in unmarked, solitary graves in deserted areas, he is tolerant of people who suffer from insurmountable pain. He recognizes the right of the desperate individual to commit suicide, when faced with unavoidable misfortune due to having led a less than good life. ${ }^{22}$ Plato takes into account the insuperable unhappiness of such people. In Laws $I V$ he states that there should be some alleviation for these people. In all other circumstances, suicide is the result of 'a spirit of slothful and abject cowardice. ${ }^{23}$

In the Republic ${ }^{24}$ Plato states that patients unable due to their suffering to live a normal life, should not receive treatment for the prolongation of life. It is evident that Plato is against active euthanasia but that he accepts passive euthanasia. In this work he refers to Asclepius, saying that it is not reasonable to prolong the suffering of a man who is not useful to himself and to society. ${ }^{24}$

Aristotle was born in c. 384 BC in Stagirus, northern Greece, and died in $323 \mathrm{BC}$. He was the son of the physician Nicomachus and studied under Plato in Athens. For Europe, Aristotle is simply 'The Philosopher'9 or, as Dante remarked, 'He is master of those that know.' Aristotle was appointed by King Philip of Macedonia to be the tutor of his son, Alexander, who later became King Alexander the Great.

Aristotle deals indirectly with euthanasia and refers to suicide in a short passages in two books: Eudemian Ethics $I V^{25}$ 
and Nichomachean Ethics $V .{ }^{26}$ In the former, he states that people seeking death are weak and depraved: 'The base among mankind, by toil o'ercome conceive a love of death,'25 and in the latter, he writes, 'But to seek death in order to escape from poverty, or the pangs of love or from pain or sorrow is not the act of courageous man, but rather of a coward.'26

Analysing Aristotle's theory of justice-just and unjust - he says that to commit suicide is to do oneself an injustice. ${ }^{1}$ It is significant that both Aristotle and Plato refer to suicide not from an ethical standpoint, but from the viewpoint of the law, supporting the theory that to commit suicide is to do oneself an injustice: 'Suicide does what the law forbids and this means that one is doing something unjust.' Later in Plato's Laws $V^{23}$ he proposes that suicide is a criminal offence, except when the act is committed under judicial order, or when one is being forced by an unavoidable misfortune or when one is so disgraced that life has become unbearable. Plato additionally says that if a person cannot resist the temptation to participate in such heinous crimes as treason or even temple robbery, then that person should rid oneself of life, looking at death as the preferable alternative. ${ }^{23}$

Taking into account that the purpose of the law is to help people become morally good, then a good legal system will make people act justly and temperately. ${ }^{1}$

Regarding the question as to whether in killing oneself one has violated justice, Aristotle says that it is not the individual but the society that has been unjustly treated by the law-breaker, and for this reason the latter should be punished by burial in disgrace. ${ }^{26}$

Epicurus (c. $341 \mathrm{BC}-270 \mathrm{BC}$ ) was born on the island of Samos, though his father Neoclis was Athenian; the family moved to Samos in 351 BC. In 306 BC, Epicurus returned to Athens, where he established his own philosophical school - the Epicurian Gardens - where he taught for 35 years. Of his numerous books, 43 have been handed down to us.

Epicurus was very much insistent on the unreasonableness of suicide, ${ }^{1}$ and states that the motives which lead somebody to kill himself are not physiological. The reasons which may lead a person to such an act are that perhaps one is tired of life or one is afraid of dying. It is reasonable for a psychologically healthy man to try to overcome this either by changing the way he lives or by facing his fear of dying. It is known that some are driven to death by this very fear. ${ }^{1}$ However, Epicurus states that each of us is free to put an end to our life if we are suffering from unbearable pain, provided this misfortune is neither brief nor intermittent. Cicero writes that Epicurus used to say 'I quit life's theatre when the play has ceased to please us.' ${ }^{1}$

Hippocrates (c. 460 BC-377 BC), a contemporary of Plato's, established scientific medicine. Lyons and Petrucelli ${ }^{27}$ write that in this regard 'From then on [5th century] into modern times, medicine in the western world and in parts of the East, would be continually under the influence of the teaching of the man named Hippocrates.'

Hippocrates, known as the father of medicine, was against active euthanasia. The well-known Hippocratic Oath prohibits doctors from administering any drug which could result in death: ${ }^{19,28}$ 'I will neither give a deadly drug to anybody if asked for it, nor will I make any suggestion to this effect.' This concurs with the principles of the Pythagorean philosophers who influenced Hippocrates and who were against any unnatural termination of life. ${ }^{19}$

However, Hippocrates seems to be in favour of passive euthanasia, in cases of gravely ill patients. In his work The $A_{r t}{ }^{29}$ he suggests that a physician should not treat a patient who has an incurable disease: 'To refuse to treat those who are overmastered by their disease realizing that in such cases, medicine is powerless.' In so stating, Hippocrates is either suggesting a kind of 'defensive' medicine, in order to protect the medical profession from failures in treatment, or he is expressing a deep respect for the inviolable nature of life. ${ }^{30}$ Lastly, another theory may also come into play, that is, to prevent physicians from the temptation to take care of a patient just for strictly professional reasons, or to obtain more fees.

\section{DISCUSSION}

Ethical considerations regarding euthanasia are as old as civilised society; since the right to life is a fundamental human right, such considerations have remained at the forefront of medical, theological and legal debate.

It is evident that most of the dramatists and philosophers in antiquity were against active euthanasia. This is in accordance with the philosophical and theological principles that life is sacred, given by the gods, and nobody can violate it. ${ }^{19}$ However, in view of a profound respect for the rules of nature, passive euthanasia ${ }^{29}$ appears to be accepted for humanitarian reasons.

There is a tendency to recognize that withholding treatment may be a reasonable and humane decision, when taking into account that Hippocrates stated that in gravely ill patients, medicine is powerless to help. ${ }^{29}$

It is true that viewpoints concerning medical ethics have evolved with the passage of time. Clinicians, policy-makers and legislators must be aware of prior concepts and current viewpoints before arriving at final decisions which must be within the limits of ethical practice imposed by law.

It is hoped that this paper will contribute to the discussion concerning passive or active euthanasia - which in many countries is still open to debate - so that the appropriate legal provisions may be adopted.

Competing interests None declared. 


\section{REFERENCES}

1 Cooper MJ. Greek philosophers on euthanasia and suicide. In: Brody $\mathrm{AB}$, ed. Suicide and Euthanasia. The Netherlands: Kluwer Academic Publishers, 1989:9-38

2 Highet G. The Classical Tradition. Greek and Roman Influence on Western Literature. New York: Oxford University Press, 1971:1-21

3 De Romilly J. A Short History of Greek Literature. (Translated by L. Doherty). Chicago: The University of Chicago Press, 1985:47-89

4 Aeschylus. Agamemnon. The Greeks. Od Hatzopoulos, ed. Athens: Kaktos Publishers, 1992:15-16

5 Gagarin M. Aeschylian Drama. Berkeley: University of California Press, 1976:57

6 Aeschylus. Prometheus Bound. The Greeks. Od Hatzopoulos, ed. Athens: Kaktos Publishers, 1992:90-91; lines 760-1

7 Oates JW, O'Neill E. The Complete Greek Drama. Aeschylus, Sophocles, Europides. New York: Random House, 1938: (a) 148, lines 731-961; (b) 429, line 221; (c) 497, lines 1193-1218

8 Winnington-Ingram PR. Sophocles. An Introduction. Cambridge: Cambridge University Press, 1985:1-10

9 Hadas M. A History of Greek Literature. New York: Columbia University Press, 1985:84-91

10 Sophocles. Antigoni. The Greeks, Od Hatzopoulos, ed. Athens: Kaktos Publishers, 1992:44-5; line 221

11 Sophocles. The Women of Trachis. The Greeks. Od Hatzopoulos, ed. Athens: Kaktos Publishers, 1992:136-7; lines 1206-8

12 The Loeb Classical Library. Euripides II. Iphigeneia in Taurica. Way A, translator. Cambridge, Mass: Harvard University Press, 1978:364; lines $973-80$

13 Euripidis. Iphigeneia in Taurica. The Greeks. Od Hatzopoulos, ed. Athens: Kaktos Publishers, 1992:363; lines 973-80

14 Euripidis. Iphigeneia in Aulis. The Greeks. Od Hatzopoulos, ed. Athens: Kaktos Publishers, 1992:114; lines 1249-52

15 The Loeb Classical Library. Euripides III. The Madness of Hercules. Cambridge, Mass: Harvard University Press, 1979:239; lines 1347-52
16 Euripides. The Madness of Hercules. The Greeks. Od Hatzopoulos, ed. Athens: Kaktos Publishers, 1992:75-7; lines 1347-52

17 Plato. Republic. The Greeks. Od Hatzopoulos, ed. Athens: Kaktos Publishers, 1992:92-5; line 407

18 Hildebrand A. Greek Culture. New York: George Brazillere Publishers, 1966:226-52

19 Edelstein L. The Hippocratic Oath; Text, Translation and Interpretation. In: Temkin O, Temkin Cl, eds, Ancient Medicine, Selected papers. of Ludwig Edelstein. Baltimore: The Johns Hopkins Press, 1967:3-63

20 Plato. Laws VI. The Greeks. Od Hatzopoulos, ed. Athens: Kaktos Publishers, 1992:80-81; line 993d.

21 Plato. Phaedo. The Greeks. Od Hatzopoulos, ed. Athens: Kaktos Publishers, 1992:70-3. lines 61c-62c

22 Plato. Gorgias. The Greeks. Od Hatzopoulos, ed. Athens: Kaktos Publishers, 1992:266-7; line 512a

23 Plato. Laws V. The Greeks. Od Hatzopoulos, ed. Athens: Kaktos Publishers, 1992:80-3; line 873c,d.

24 Plato. Republic II. The Greeks. Od Hatzopoulos, ed. Athens: Kaktos Publishers, 1992:90-7; lines 406e-407e

25 The Loeb Classical Library. Aristotle. Eudemian Ethics. Rackham H, translator. Cambridge, Mass: Harvard University Press, 1982:320-4; line 1230a

26 The Loeb Classical Library. Aristotle. Nichomachean Ethics. Vol V, XIX. Cambridge Mass: Harvard University Press, 1982:253-322; lines 1116a, 1138a, 11-15

27 Lyons A, Petrucelli RJ. Medicine: An Illustrated History. New York: Abradale Press H Abrams Inc, 1987:206-7

28 The Loeb Classical Library. Hippocrates. Vol I. Goold GB, ed. Jones WHS, translator. Cambridge Mass: Harvard University Press, 1995:289-301

29 The Loeb Classical Library. Hippocrates. Vol II. Goold GB, ed. Jones WHS, translator. Cambridge Mass: Harvard University Press, 1995:185-217

30 Marketos SG, Skiadas P. Plato: The Most Important Proponent of Euthanasia in Ancient Greece. Athens: Asclepios, 1999/2000: 12;32-35 